DOI: $10.31933 /$ JEMSI

Received: 6 Agustus 2020, Revised: 25 Agustus 2020, Publish: 22 September 2020

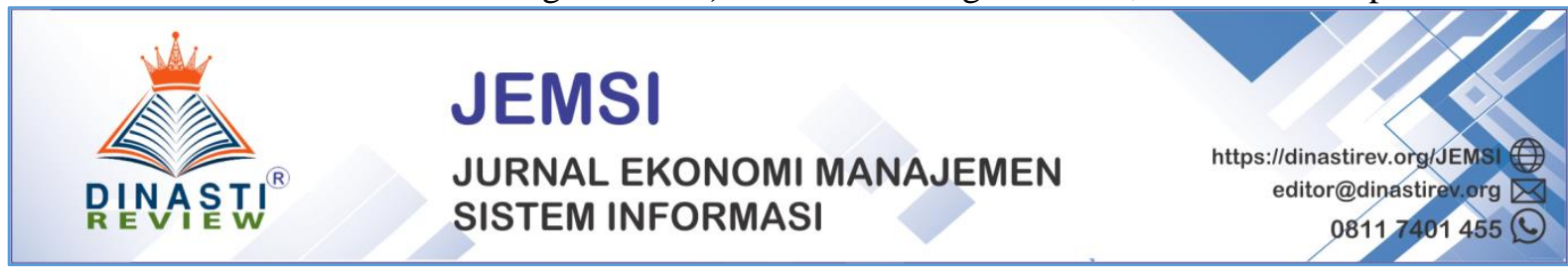

\title{
KUALITAS PRODUK, WORD OF MOUTH DAN MINAT BELI DALAM PEMBELIAN
}

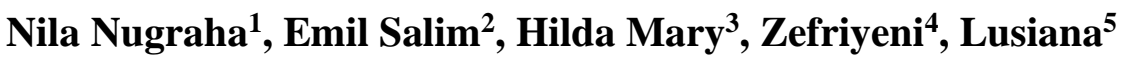 \\ 1) Universitas Putra Indonesia "YPTK" Padang, Sumatera Barat, Indonesia \\ 2) Universitas Putra Indonesia "YPTK" Padang, Sumatera Barat, Indonesia \\ 3) Universitas Putra Indonesia "YPTK" Padang, Sumatera Barat, Indonesia, hildamary @ upiyptk.ac.id \\ 4) Universitas Putra Indonesia "YPTK" Padang, Sumatera Barat, Indonesia \\ 5) Universitas Putra Indonesia "YPTK" Padang, Sumatera Barat, Indonesia
}

\section{Corresponding Author: First Author}

\begin{abstract}
Abstrak: Penjualan excavator komatsu yang mengalami kenaikan dan penurunan yang tidak stabil, maka diupayakan pemasaran dengan cara membicarakan (word of mouth), mempromosikan, merekomendasikan dan menjual produk atau merek kepada pelanggan. Research ini bertujuan untuk mengetahui seberapa besar pengaruh kualitas produk, word of mouth, minat beli dalam pembelian excavator komatsu. Metode yang digunakan bersifat kuantitatif dengan responden 90 orang. Dalam upaya meningkatkan Keputusan Pembelian dan menambah Minat Beli Konsumen bertambah perusahaan harus memperhatikan Word Of Mouth karena terbukti memberikan pengaruh yang besar terhadap Keputusan Pembelian tanpa mengabaikan variabel lain yang tidak diteliti.
\end{abstract}

Kata Kunci: kualitas produk, word of mouth, minat beli dan keputusan pembelian

\section{PENDAHULUAN}

Word of mouth merupakan usaha pemasaran yang memicu konsumen untuk membicarakan, mempromosikan, merekomendasikan dan menjual produk atau merek kita kepada pelanggan lainnya (Nugroho, 2018). Minat beli adalah pengintegrasi yang dilakukan untuk mengkombinasikan serta mengevaluasi beberapa perilaku alternatif dan memilih salah satu diantaranya (Wijaksana, 2019).

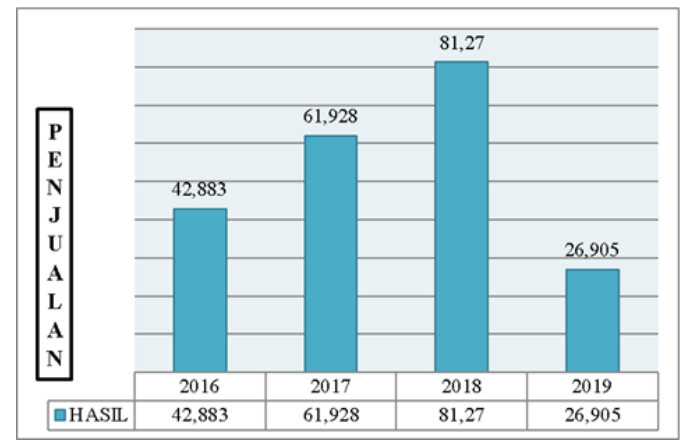




\section{Gambar 1. Data Penjualan Excavator Komatsu 2016-2019}

Berdasarkan dari grafik batang diatas volume penjualan Excavator Komatsu mengalami naik turun setiap tahun. Pada tahun 2016 jumlah pendapatan sebesar Rp. 42.883.690.000 tahun 2017 mengalami kenaikan pendapatan sebesar Rp. 61.928.075.000, pada tahun 2018 mengalami kenaikan kembali sebesar Rp. 81.270.000.000 selanjutnya pada tahun 2019 kembali mengalami penurunan sebesar Rp. 26.905.000.000.

Dapat dilihat dari data penjualan PT. United Tractors bahwa penjualan komatsu selalu mengalami kenaikan dan penurunan yang tidak stabil kerena hasil penjualan mengalami perubahaan, oleh karena itu kualitas produk komatsu lebih ditingkatkan dengan adanya usaha membicarakan dan mempromosikan kembali merek komatsu sehingga konsumen tidak mengalami perubahan minat beli atau terjadinya perubahan pembelian merek lainnya.

Dari fenomena diatas, terindikasi bahwa terjadinya fluktuasi pada penjualan Excavator Komatsu pada PT. United Tractors disinyalir disebabkan oleh kualitas produk, word of mouth dan minat beli tersebut terhadap keputusan pembelian dapat dilihat dari berbagai penelitian yang dilakukan oleh penelitian terdahulu.

\section{KAJIAN PUSTAKA Kualitas Produk}

Kualitas produk adalah segala sesuatu yang dapat memuaskan keinginan atau kebutuhan. Pembuatan produk lebih baik diorientasikan pada keinginan pasar atau selera konsumen. Produk yang di rancang perusahaan harus memiliki kualitas yang baik, serta wajib dikomunikasikan secara terus menerus kepada konsumen. Hal ini harus dilakukan agar produk tetap berada di dalam ingatan konsumen bahkan menjadi pilihan utama konsumen. Satu satunya atribut yang sulit ditiru adalah merek yang kuat (Riyono, 2016).

\section{Word Of Mouth}

(Assael, 2015) mengungkapkan "word of mouth interpersonal communication between two or more individuals such a s members of a reference group or customer and a salesperson". Assail menjelaskan bahwa komunikasi dari mulut ke mulut adalah komunikasi secara pribadi (interpersonal) antara dua atau lebih sebagai anggota dari suatu kelompok atau seorang pelanggan dengan seorang sales person.

\section{Minat Beli}

Minat beli adalah kecenderungan tindakan individu yang terkait terhadap suatu merek (Rachbini, 2018). Sedangkan menurut (Emes, 2019) mengungkapkan pengertian minat beli adalah perilaku pelanggan dimana pelanggan merespon positif terhadap apa yang telah diberikan oleh suatu perusahaan dan berminat untuk melakukan kunjungan kembali atau mengkomsusi kembali produk perusahaan tersebut.

\section{Keputusan Pembelian}

Keputusan pembelian adalah keputusan konsumen mengenai preferensi atas merekmerek yang ada di dalam kumpulan pilihan (Sakti, 2020). Proses keputusan pembelian terdiri dari lima tahap yaitu pengenalan masalah, pencarian informasi, evaluasi alternatif, keputusan pembelian dan perilaku pasca pembelian. Sekarang ini sering di temukan produk atau jasa yang beredar di pasaran tidak memiliki strategi pemasaran terutama strategi kualitas produk 
dan citra merek yang baik. Para produsen yang menjual produk tanpa melihat kualitas produk biasanya hanya ingin mendapatkan keuntungan semata tanpa mempertimbangkan faktorfaktor lain.

Diagram path analysis dari variabel tersebut adalah sebagai berikut:

Gambar 2

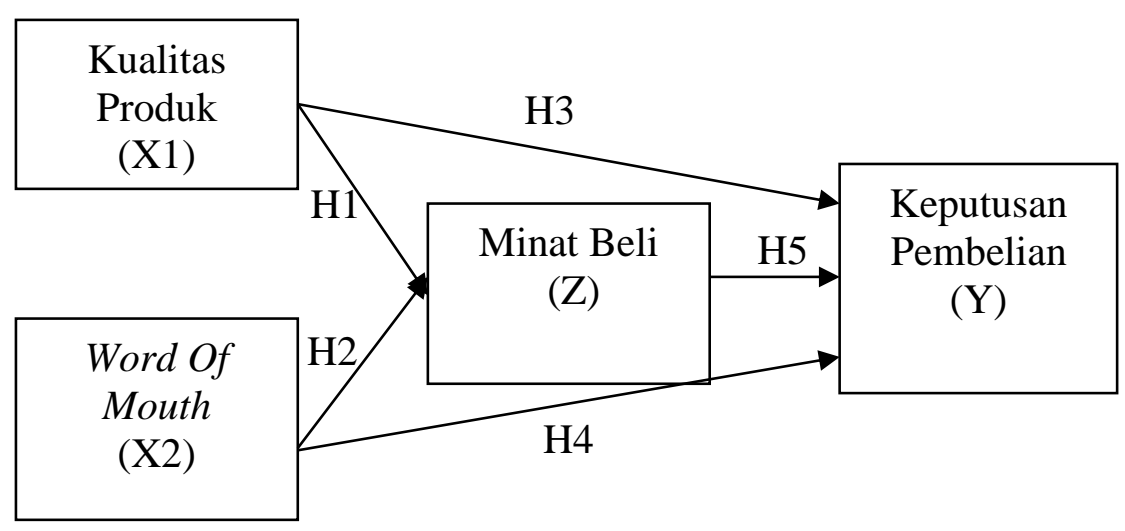

Gambar 2. Diagram Path Analysis

\section{METODE PENELITIAN}

Metode penelitian kuantitatif dengan analisis data berupa deskriptif dimana pengumpulan data bersumber pada kuesioner yang diisi oleh responden penyajian ini bertujuan untuk memberikan gambaran atau deskripsi dari suatu data yang dilihat dari jumlah sampel, dengan jumlah responden 90 orang konsumen Excavator Komatsu PT. United Tractors Tbk. Padang.

\section{HASIL DAN PEMBAHASAN}

\section{Analisis Korelasi}

Tabel 1. Correlations

\begin{tabular}{|c|c|c|c|c|c|}
\hline \multicolumn{6}{|c|}{ Correlations } \\
\hline & & Keputusan & Kualitas Produk & Word Of Mouth & Minat Beli \\
\hline & & Pembelian & & & \\
\hline \multirow{3}{*}{$\begin{array}{l}\text { Keputusan } \\
\text { Pembelian }\end{array}$} & Pearson Correlation & 1 & $242^{*}$ &, $535^{* *}$ &, $795^{* *}$ \\
\hline & Sig. (2-tailed) & &, 022 & ,000 & ,000 \\
\hline & $\mathrm{N}$ & 90 & 90 & 90 & 90 \\
\hline \multirow{3}{*}{ Kualitas Produk } & Pearson Correlation & ,242* & 1 &, $213^{*}$ &, $272^{* *}$ \\
\hline & \begin{tabular}{|l|} 
Sig. (2-tailed) \\
\end{tabular} &, 022 & & ,044 & ,009 \\
\hline & $\mathrm{N}$ & 90 & 90 & 90 & 90 \\
\hline \multirow{3}{*}{ Word Of Mouth } & Pearson Correlation &, $535^{* *}$ &, $213^{*}$ & 1 &, $452^{* * *}$ \\
\hline & Sig. (2-tailed) & ,000 &, 044 & & ,000 \\
\hline & $\mathrm{N}$ & 90 & 90 & 90 & 90 \\
\hline \multirow{3}{*}{ Minat Beli } & Pearson Correlation &, $795^{* *}$ & $272^{* * *}$ &, $452^{* *}$ & 1 \\
\hline & \begin{tabular}{|l|} 
Sig. (2-tailed) \\
\end{tabular} &, 000 & ,009 &, 000 & \\
\hline & $\mathrm{N}$ & 90 & 90 & 90 & 90 \\
\hline
\end{tabular}

*. Correlation is significant at the 0.05 level (2-tailed). 
**. Correlation is significant at the 0.01 level (2-tailed).

Interprestasi dari hasil analisis tabel 1 diatas dapat dilihat korelasi antara masing-masing variabel, yaitu :

1. Korelasi antara variabel Kualitas Produk (X1) dengan Keputusan Pembelian (Y) adalah 0,242 . Hubungan kedua variabel rendah dan searah, dengan nilai probabilitasnya 0,022 $<0,05$ sehingga dapat disimpulkan bahwa kedua variabel signifikan.

2. Korelasi antara variabel Word Of Mouth (X2) dengan Keputusan Pembelian (Y) adalah 0,535. Hubungan kedua variabel sedang dan searah, dengan nilai probabilitasnya 0,000 $<0,05$ sehingga dapat disimpulkan bahwa kedua variabel signifikan.

3. Korelasi antara variabel Minat Beli (Z) dengan Keputusan Pembelian (Y) adalah 0,795. Hubungan kedua variabel sangat kuat dan searah, dengan nilai probabilitasnya $0,000<$ 0,05 sehingga dapat disimpulkan bahwa kedua variabel signifikan.

\section{Analisis Linier Berganda}

\section{Tabel 2. Regresi Linier Berganda (1)}

\begin{tabular}{|c|c|c|c|c|c|c|}
\hline \multicolumn{7}{|c|}{ Coefficients ${ }^{a}$} \\
\hline \multicolumn{2}{|c|}{ Model } & \multicolumn{2}{|c|}{$\begin{array}{c}\text { Unstandardized } \\
\text { Coefficients }\end{array}$} & \multirow{2}{*}{$\begin{array}{c}\begin{array}{c}\text { Standardized } \\
\text { Coefficients }\end{array} \\
\text { Beta }\end{array}$} & \multirow{2}{*}{$\mathrm{T}$} & \multirow[t]{2}{*}{ Sig. } \\
\hline & & $\mathrm{B}$ & Std. Error & & & \\
\hline \multirow{3}{*}{1} & (Constant) & 20,876 & 3,927 & & 5,316 & 000 \\
\hline & Kualitas Produk & ,242 & , 126 &, 185 & 1,925 &, 057 \\
\hline & Word Of Mouth & , 480 & ,111 & ,413 & 4,307 &, 000 \\
\hline
\end{tabular}

a. Dependent Variable: Minat Beli

Tabel 3. Regresi Linier Berganda (2)

\begin{tabular}{|c|c|c|c|c|c|c|}
\hline \multicolumn{7}{|c|}{ Coefficients $^{\mathbf{a}}$} \\
\hline \multirow{2}{*}{\multicolumn{2}{|c|}{ Model }} & \multicolumn{2}{|c|}{$\begin{array}{c}\text { Unstandardized } \\
\text { Coefficients }\end{array}$} & \multirow{2}{*}{$\begin{array}{c}\text { Standardized } \\
\text { Coefficients } \\
\text { Beta }\end{array}$} & \multirow[t]{2}{*}{$\mathrm{T}$} & \multirow[t]{2}{*}{ Sig. } \\
\hline & & $\mathrm{B}$ & Std. Error & & & \\
\hline \multirow{4}{*}{1} & (Constant) & 8,450 & 3,061 & & 2,760 & ,007 \\
\hline & Kualitas Produk & ,008 & ,087 & ,006 & ,095 & ,925 \\
\hline & Word Of Mouth &, 262 &, 083 & ,220 & 3,149 & ,002 \\
\hline & Minat Beli & ,710 & ,073 & ,694 & 9,785 & ,000 \\
\hline
\end{tabular}

a. Dependent Variable: Keputusan Pembelian

Berikut Persamaan regresinya yaitu:

$\mathrm{Z}=20,876+0,242 \mathrm{X} 1+0,480 \mathrm{X} 2+\mathrm{e}$

$\mathrm{Y}=8,450+0,008 \mathrm{X} 1+0,262 \mathrm{X} 2+0,710 \mathrm{Z}+\mathrm{e}$ 
Interprestasi berdasarkan persamaan tersebut dapat diartikan sebagai berikut :

1. Konstanta sebesar 20,876 artinya apabila Kualitas Produk dan Word Of Mouth tidak ada maka Minat Beli tetap sebesar konstanta 20,876.

2. Koefisien regresi Positif (searah) sebesar 0,242 artinya apabila Kualitas Produk ditingkatkan sebesar satu satuan bobot, dengan asumsi Word Of Mouth diabaikan maka akan mengakibatkan peningkatan Minat Beli sebesar 0,242.

3. Koefisien regresi Positif (searah) 0,480 artinya apabila Word Of Mouth ditingkatkan sebesar satu satuan bobot, dengan asumsi Kualitas Produk diabaikan diabaikan maka akan mengakibatkan peningkatan Minat Beli sebesar 0,480.

4. Konstanta sebesar 8,450 artinya apabila Kualitas Produk, Word Of Mouth dan Minat Beli diabaikan maka Keputusan Pembelian adalah sebesar 8,450.

5. Koefisien regresi Positif (searah) sebesar 0,008 artinya apabila Kualitas Produk ditingkatkan sebesar satu satuan bobot, dengan asumsi Word Of Mouth dan Minat Beli diabaikan maka akan mengakibatkan peningkatan Keputusan Pembelian sebesar 0,008.

6. Koefisien regresi Positif (searah) sebesar 0,262 artinya apabila Word Of Mouth ditingkatkan sebesar satu satuan bobot, dengan asumsi Kualitas Produk dan Minat Beli diabaikan diabaikan maka akan mengakibatkan peningkatan Keputusan Pembelian sebesar 0,262.

7. Koefisien regresi positif (searah) sebesar 0,710 artinya apabila Minat Beli ditingkatkan sebesar satu satuan bobot, dengan asumsi Kualitas Produk dan Word Of Mouth diabaikan maka akan mengakibatkan peningkatan Keputusan Pembelian sebesar 0,710.

Gambar 3

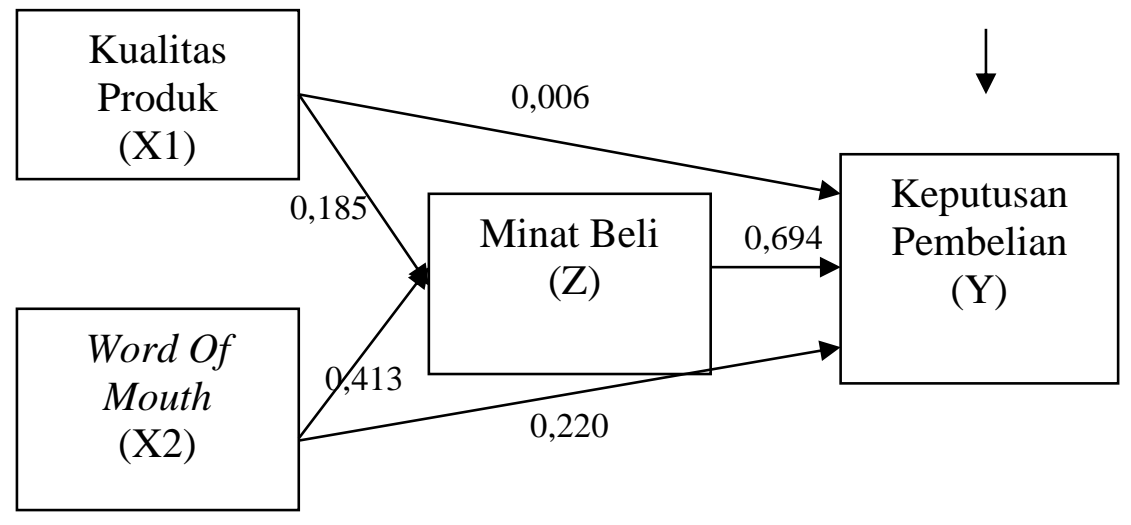

Gambar 3. Diagram Analysis Jalur

Berdasarkan Gambar diatas dapat diketahui bahwa pengaruh langsung serta pengaruh total dari penelitian ini adalah sebagai berikut :

1. Analisis Jalur Kualitas Produk terhadap Keputusan Pembelian melalui Minat Beli

Pengaruh langsung Kualitas Produk terhadap Keputusan Pembelian sebesar 0,006, Pengaruh Kualitas Produk terhadap Minat Beli sebesar -0,185 dan pengaruh Minat Beli terhadap Keputusan Pembelian sebesar 0,694 dengan demikian pengaruh tidak langsung Kualitas Produk terhadap Keputusan Pembelian melalui Minat Beli sebesar 0,185 x 0,694 = 
0,128. Pengaruh total Kualitas Produk terhadap Keputusan Pembelian yaitu 0,006 + $(0,128)=$ 0,134 Hasil perhitungan menunjukan bahwa pengaruh tidak langsung Kualitas Produk terhadap Keputusan Pembelian melalui Minat Beli lebih besar dibandingkan dengan pengaruh langsung Kualitas Produk terhadap Keputusan Pembelian, sehingga dapat disimpulkan bahwa Minat Beli mampu menjadi variabel intervening atau memediasi antara Kualitas Produk terhadap Keputusan Pembelian

2. Analisis Jalur Word Of Mouth terhadap Keputusan Pembelian melalui Minat Beli

Pengaruh langsung Word Of Mouth terhadap Keputusan Pembelian sebesar 0,220, Pengaruh Word Of Mouth terhadap Minat Beli sebesar 0,413 dan pengaruh Minat Beli terhadap Keputusan Pembelian sebesar 0,694 dengan demikian pengaruh tidak langsung Word Of Mouth terhadap Keputusan Pembelian melalui Minat Beli sebesar 0,413 x 0,694= 0,286. Pengaruh total Word Of Mouth terhadap Keputusan Pembelian yaitu 0,220 + $(0,286)=$ 0,506. Hasil perhitungan menunjukan bahwa pengaruh tidak langsung Word Of Mouth terhadap Keputusan Pembelian melalui Minat Beli lebih besar dibandingkan dengan pengaruh langsung Word Of Mouth terhadap Keputusan Pembelian, sehingga dapat disimpulkan bahwa Minat Beli mampu menjadi variabel intervening antara Word Of Mouth terhadap Keputusan Pembelian.

\section{Pembahasan}

Berdasarkan hasil penelitian yang telah dilakukan, maka penulis dapat mengimplementasikan hal-hal sebagai berikut :

1. Pengaruh Kualitas Produk (X1) terhadap Minat Beli (Z)

Dimana terlihat t-hitung 1,925 dan t-tabel 1,663 dimana t-hitung lebih besar dari ttabel $(1,925>1,663)$ atau tingkat signifikan lebih kecil dari dari alpha $(0,057<0,05)$ maka dapat diperoleh $\mathrm{HO}$ ditolak Ha diterima. Hasil penelitian menunjukan bahwa kompensasi berpengaruh positif dan signifikan terhadap Minat Beli.

2. Pengaruh Word Of Mouth (X2) terhadap Minat Beli (Z)

Dimana terlihat t-hitung 4,307 dan t-tabel 1,663 dimana t-hitung lebih besar dari ttabel $(4,307>1,663)$ atau tingkat signifikan lebih kecil dari dari alpha $(0,000<0,05)$ maka dapat diperoleh $\mathrm{H} 0$ ditolak Ha diterima. Hasil penelitian menunjukan bahwa Word Of Mouth berpengaruh positif dan signifikan terhadap Minat Beli. (Rivan Kojongian, Joyye Lapian, 2019) mengungkapkan hasil penelitian ini menunjukkan bahwa word of mouth berpengaruh positif dan signifikan terhadap minat beli

3. Pengaruh Kualitas Produk (X1) terhadap Keputusan Pembelian (Y)

Dimana terlihat t-hitung 0,095 dan t-tabel 1,663 dimana t-hitung lebih kecil dari ttabel $(0,095<1,663)$ atau tingkat signifikan lebih besar dari dari alpha $(0,925>0,05)$ maka dapat diperoleh $\mathrm{H0}$ diterima Ha ditolak. Hasil penelitian menunjukan bahwa Kualitas Produk berpengaruh positif dan tidak signifikan terhadap Keputusan Pembelian. Penelitian sebelumnya menyatakan kualitas produk berpengaruh terhadap keputusan pembelian (Ayuningtias dan Waluyo, 2017)

4. Pengaruh Word Of Mouth (X2) terhadap Keputusan Pembelian (Y)

Dimana terlihat t-hitung 3,002 dan t-tabel 1,663 dimana t-hitung lebih besar dari ttabel $(3,149>1,663)$ atau tingkat signifikan lebih kecil dari dari alpha $(0,000<0,05)$ maka dapat diperoleh $\mathrm{H} 0$ ditolak Ha diterima Hasil penelitian menunjukan bahwa Word Of Mouth berpengaruh positif dan signifikan terhadap Keputusan Pembelian. 
5. $\quad$ Pengaruh Minat Beli (Z) terhadap Keputusan Pembelian (Y)

Dimana terlihat t-hitung 9,785 dan t-tabel 1,663 dimana t-hitung lebih besar dari ttabel $(9,785>1,663)$ atau tingkat signifikan lebih kecil dari dari alpha $(0,000<0,05)$ maka dapat diperoleh $\mathrm{H0}$ ditolak Ha diterima. Hasil penelitian menunjukan bahwa Minat Beli berpengaruh positif dan signifikan terhadap Keputusan Pembelian.

\section{KESIMPULAN DAN SARAN}

Berdasarkan kajian hasil penelitian dan pembahasan yang telah dipaparkan sebelumnya maka dapat ditarik kesimpulan sebagai berikut :

1. Bahwa terdapat pengaruh positif dan signifikan Kualitas Produk (X1) terhadap Minat Beli (Z) pada Excavator Komatsu pada PT. United Tractors Tbk Kota Padang

2. Bahwa terdapat pengaruh positif dan signifikan Word Of Mouth (X2) terhadap Minat Beli (Z) pada Excavator Komatsu pada PT. United Tractors Tbk Kota Padang

3. Bahwa terdapat pengaruh positif dan signifikan Kualitas Produk (X1) terhadap Keputusan Pembelian (Y) pada Excavator Komatsu di PT. United Tractors Tbk Kota Padang

4. Bahwa terdapat pengaruh positif dan signifikan Word Of Mouth (X2) terhadap Keputusan Pembelian (Y) pada Excavator Komatsu pada PT. United Tractors Tbk Kota Padang

5. Bahwa terdapat pengaruh positif dan signifikan Minat Beli (Z) terhadap Keputusan Pembelian (Y) pada Excavator Komatsu pada PT. United Tractors Tbk Kota Padang

\section{DAFTAR RUJUKAN}

Assael dan kusumawati. (n.d.). pengaruh atribut produk dan word of mouth terhadap keputusan pembelian. Serambi Konstruktivis, 1, 15.

Edwin Japarianto, S. A. (2020). Pengaruh Tampilan Web dan Harga Terhadap Minat Beli dengan Kepercayaan sebagai Intervening Variabel Pada E-Commerce Shope. 14(1), 35-43. https://doi.org/10.9744/pemasaran.14.1.35

Ernst and Haar. (2019). The Effect of Product Quality and Service Quality on Multi Purpose Loan Credit ( KMG ) Customer Satisfaction of Customs in Bank Sumut of Iskandar Muda Branch. International Journal Of Research And Review, 7(2 february 2020), 389. Fandy Tjiptono, P. . (2019). Strategi Produk.

Gunawan, A. J. (2018). Role of Consumer Buying Interest as an Intervening Variable in Increasing Go-Jek Customer Satisfaction in Aceh, Indonesia. Advances in Social Science, Education and Humanities Research, 292(Agc), 516-521.

The Effect of Entrepreneur' s Orientation on the Survival of Small and Medium Enterprises of the Fishery Processing Groups in Makassar City Raudhah Mukhsin ISSN 2303100X P. Raudhah Mukhsin, Palmarudi Mappigau, Andi Nixia TenriawaruAndi Nixia Tenriawaru, 6(2), 188-193.

Nugroho. (2018). Pengaruh Atribut Produk dan Word Of Mouth terhadap Keputusan Pembelian Buku Pada PT.Masmedia Buasa Pustaka Cabang Banda Aceh. Serambi Konstruktivis, 1, 16.

Rachbini. (2018). Pengaruh Kualitas Produk, Citra Merek dan Celebrity Endorser terhadap Keputusan Pembelian Smarthphone Melalui Minat Beli sebagai Variabel Intervening. Ejournal Administrasi Bisnis, 7(4, 2019), 414. 
Riyono dan Gigih Erlik Budiharja. (2016). pengaruh kualitas produk dan citra merek terhadap keputusan pembelian minuman frestea. Ilmiah ,Manajemen, Ekonomi Dan Akuntansi, 4, 177.

Sakti Riana Fatmaningrum, Susanto, \& M. F. (2020). Pengaruh Kualitas Produk Dan Citra Merek Terhadap Keputusan Pembelian Minuman Frestea. 4(1), 176-188.

Sugiyono. (2015). metodelogi penelitian. In metodelogi penelitian.

Sugiyono. (2016). metode pengumpulan data. JIMEK : Jurnal Ilmiah Mahasiswa Ekonomi, 2(1 JULI 2019), 142.

Sugiyono. (2019). Metode Penelitian Kuantitatif Kualitatif.

Wicaksono. (2016). Pengaruh Kualitas Produk, Citra Merek dan Celebrity Endorser terhadap Keputusan Pembelian Smartphone Melalui Minat Beli Sebagai Variabel Intervening. EJournal Administrasi Bisnis, 7, 411.

Wijaksana dan Alivia. (2019). Pengaruh Minat Beli. E-Journal Administrasi Bisnis. 